Corrigendum

\title{
Corrigendum to "Sedative and Hypnotic Activities of the Methanolic and Aqueous Extracts of Lavandula officinalis from Morocco"
}

\author{
Rachad Alnamer ${ }^{10},{ }^{1}$ Katim Alaoui, ${ }^{2}$ El Houcine Bouidida, ${ }^{3}$ Abdelaziz Benjouad, ${ }^{1}$ \\ and Yahia Cherrah ${ }^{2}$ \\ ${ }^{1}$ Laboratory of Genetic Immunology and Biochemistry, Department of Biology, Faculty of Science, \\ Mohammed V Agdal University, BP 6203, Rabat Instituts, Agdal, Rabat, Morocco \\ ${ }^{2}$ Laboratory of Pharmacology and Toxicology, Department of Drugs Sciences, Faculty of Medicine and Pharmacy, \\ Mohammed V Souissi University, ERTP, BP 6203, Rabat Instituts, Agdal, Rabat, Morocco \\ ${ }^{3}$ National Laboratory of Drugs Controlled, BP 6203, Rabat Instituts, Agdal, Rabat, Morocco \\ Correspondence should be addressed to Katim Alaoui; alaouikma@yahoo.fr
}

Received 18 May 2020; Accepted 28 May 2020; Published 16 November 2020

Copyright ( 92020 Rachad Alnamer et al. This is an open access article distributed under the Creative Commons Attribution License, which permits unrestricted use, distribution, and reproduction in any medium, provided the original work is properly cited.

In the article titled "Sedative and Hypnotic Activities of the Methanolic and Aqueous Extracts of Lavandula officinalis from Morocco" [1], there was a substantial amount of material from previously published articles, including the following sources cited as $[4,6,31]$ :

(i) F. Huang, Y. Xiong, L. Xu, S. Ma, and C. Dou, "Sedative and hypnotic activities of the ethanol fraction from Fructus Schisandrae in mice and rats," Journal of Ethnopharmacology, vol. 110, no. 3, pp. 471-475, 2007. [2].

(ii) G. Pérez-Ortega, P. Guevara-Fefer, M. Chávez et al., "Sedative and anxiolytic efficacy of Tilia americana var. mexicana inflorescences used traditionally by communities of State of Michoacan, Mexico," Journal of Ethnopharmacology, vol. 116, no. 3, pp. 461-468, 2008. [3].

(iii) G. Zapata-Sudo, T. C. F. Mendes, M. A. Kartnaller et al., "Sedative and anticonvulsant activities of methanol extract of Dorstenia arifolia in mice," Journal of Ethnopharmacology, vol. 130, no. 1, pp. 9-12, 2010. [4].

Additionally, the article was also found to contain a substantial amount of material, without citation, from previously published articles, including the following sources: (iv) E. Aguirre-Hernández, A. L. Martínez, M. E. González-Trujano, J. Moreno, H. Vibrans, M. SotoHernández, "Pharmacological evaluation of the anxiolytic and sedative effects of Tilia americana $\mathrm{L}$. var. mexicana in mice," Journal of Ethnopharmacology, vol. 109, no. 1, 2007. [5].

(v) O. O. Adeyemi, A. J. Akindele, O. K. Yemitan, F. R. Aigbe, F. I. Fagbo, "Anticonvulsant, anxiolytic and sedative activities of the aqueous root extract of Securidaca longepedunculata Fresen.," Journal of Ethnopharmacology, vol. 130, no. 2, 2010. [6].

\section{References}

[1] R. Alnamer, K. Alaoui, E. H. Bouidida, A. Benjouad, and Y. Cherrah, "Sedative and hypnotic activities of the methanolic and aqueous extracts of Lavandula officinalis from Morocco," Advances in Pharmacological Sciences, vol. 2012, Article ID 270824, 5 pages, 2012.

[2] F. Huang, Y. Xiong, L. Xu, S. Ma, and C. Dou, "Sedative and hypnotic activities of the ethanol fraction from Fructus Schisandrae in mice and rats," Journal of Ethnopharmacology, vol. 110, no. 3, pp. 471-475, 2007.

[3] G. Pérez-Ortega, P. Guevara-Fefer, M. Chávez et al., "Sedative and anxiolytic efficacy of Tilia americana var. mexicana inflorescences used traditionally by communities of State of 
Michoacan, Mexico," Journal of Ethnopharmacology, vol. 116, no. 3, pp. 461-468, 2008.

[4] G. Zapata-Sudo, T. C. F. Mendes, M. A. Kartnaller et al., "Sedative and anticonvulsant activities of methanol extract of Dorstenia arifolia in mice," Journal of Ethnopharmacology, vol. 130, no. 1, pp. 9-12, 2010.

[5] E. Aguirre-Hernández, A. L. Martínez, M. E. González-Trujano, J. Moreno, H. Vibrans, and M. Soto-Hernández, "Pharmacological evaluation of the anxiolytic and sedative effects of Tilia americana L. var. mexicana in mice," Journal of Ethnopharmacology, vol. 109, no. 1, pp. 140-145, 2007.

[6] O. O. Adeyemi, A. J. Akindele, O. K. Yemitan, F. R. Aigbe, and F. I. Fagbo, "Anticonvulsant, anxiolytic and sedative activities of the aqueous root extract of Securidaca longepedunculata Fresen," Journal of Ethnopharmacology, vol. 130, no. 2, pp. 191-195, 2010. 